\title{
Secukinumab treatment in spondyloarthritis: Retention rate and effectiveness data at 12 months - data from the Romanian Registry of Rheumatic Diseases
}

\author{
Corina Mogosan ${ }^{1,2}$, Ruxandra Ionescu ${ }^{2,3}$, Simona Rednic ${ }^{4,5}$, Magda Parvu ${ }^{6}$, Elena Rezus ${ }^{7}$, \\ Catalin Codreanu ${ }^{1,2}$ \\ 1"Dr. Ion Stoia" Center of Rheumatic Diseases, Bucharest, Romania \\ 2"Carol Davila" University of Medicine and Pharmacy, Bucharest, Romania \\ 3"Sf. Maria" Clinical Hospital, Department of Rheumatology and Internal Medicine, Bucharest, Romania \\ ${ }^{4}$ Rheumatology, Emergency County Teaching Hospital, Cluj-Napoca, Romania \\ 5"Iuliu Hatieganu" University of Medicine and Pharmacy, Cluj-Napoca, Romania \\ ${ }^{6}$ Department of Rheumatology, "Colentina" Clinical Hospital, Bucharest, Romania \\ 7"Gr.T. Popa" University of Medicine and Pharmacy, lasi, Romania
}

\begin{abstract}
Background. Registries data are important contributors to complement information provided by randomized controlled trial reports in terms of effectiveness and safety evaluation for anti-rheumatic drugs used in clinical practice.

Objectives. We aimed to estimate the 12 month secukinumab retention rate and effectiveness in patients with axial spondyloarthritis. Data from the Romanian Registry of Rheumatic Diseaases (RRBR, in Romanian) were collected for all patients who received at least one course of secukinumab. The retention rate was calculated using KaplanMeier method with log-rank test. Effectiveness was assessed at 6-month and at 12-month for inactive disease and for low disease activity states (Bath Ankylosing Spondylitis Disease Activity Index (BASDAI < 2 and BASDAI < 4) and Ankylosing Spondylitis Disease Activity Score (ASDAS < 1.3 and ASDAS < 2.1).

Results. The study included 616 patients with axial spondyloarthritis who received secukinumab. 226 patients were naïve to biologic treatments; 220 patients had one prior bDMARD; 170 patients used two or more bDMARDs. The overall 6-months and 12 -months secukinumab retention rates were $68 \% / 49 \%$ with significant differences in favour of biologic naïve patients: bDMARD-naïve: $78 \% / 58 \%$, 1 prior bDMARD: $63 \% / 45 \%, \geq 2$ prior bDMARDs: $61 \% / 41 \%$. The 6-month and 12-month results for effectiveness: overall BASDAI <2: 54\%/66\%; overall BASDAI < 4: $91 \% / 97 \%$; overall ASDAS < 1.3: $14 \% / 19 \%$; overall ASDAS < 2.1: $53 \% / 73 \%$. The number of previous bDMARDs had an impact on effectiveness, with more responders being observed in the biologic naïve group.

Conclusions. Our results show that the best retention rate for secukinumab treatment, as well as efficacy, is attained for the bio-naive treatment group. The main reason for discontinuation of secukinumab treatment is secondary loss of efficacy
\end{abstract}

Keywords: secukinumab, registry, retention rate, effectiveness

\section{INTRODUCTION}

In patients with axial spondyloarthritis and persistently high disease activity despite conventional treatment, biologic disease modifying antirheumatic drugs (bDMARDs) are used, most often tumour necrosis factor inhibitors (TNFi) (1-4). To date, together with the extensive use of TNF alpha blockers in
ax-SpA, there is comprehensive knowledge in terms of their effectiveness as well as safety.

Secukinumab, a fully human IgG1 kappa monoclonal antibody directed against IL-17A, was approved by the European Medicines Agency for use in r-axSpA in 2015. Subsequently, it became available in Romania in 2017. It is commercially available for use also in psoriasis and psoriatic arthritis, for nr-ax- 
$\mathrm{SpA}$ and is being investigated as a potential treatment for uveitis (5).

Being recently introduced, the efficacy and safety data on secukinumab in axSpA has so far originatede exclusively from randomized control trials (RCT), with limited evidence from real-world practice. In order to improve data collection and knowledge regarding treatment of SpA, in 2017 the European Spondyloarthritis Research Collaboration Network (EuroSpA) was initiated, which aims to develop and investigate research questions by using prospective, real-life data on patients with SpA (6-9). Research questions focus on routine care treatment of patients with SpA in a European context (9). Since EuroSpA was developed, more data from real practice settings became available, including reports on TNF blockers and secukinumab use from the European Patient Registries. Romania is being an active part of the EuroSpA network through the Romanian Registry of Rheumatic Diseases (RRBR). The RRBR database was developed in 2013 and it currently comprises all the patients with inflammatory rheumatic conditions treated with biological agents in the country, giving an insider perspective in terms of efficacy and safety for the use of these drugs.

EuroSpa recently published data related to drug retention of secukinumab in patients with $\operatorname{axSpA}$ from 13 European Registries, showing large variability in results across countries (9). The primary aim of this observational study is to evaluate the retention rate of secukinumab at 12 months of treatment exposure in ax-SpA in Romania and to compare our results with European study results. Secondary outcomes were to determine efficacy parameters at 6 and 12 months for ax-SpA population treated with secukinumab, in different clinical scenarios, based on the prior use of biological disease modifying anti-rheumatic drugs (bDMARDs).

\section{MATERIALS AND METHODS}

RRBR is a national electronic database. Data are added to the RRBR by the treating rheumatologist and are updated each six months, except when reporting adverse events, which may be done at any time. All collected data for the present study came from RRBR database and included: demography (age, sex, height, weight, smoking habit), SpA characteristics (disease duration, time since diagnosis and start of the first biologic, ESR, C reactive protein) and treatment options - with focus on secukinumab, the evolution on secukinumab exposure during the first 12 months, efficacy parameters (BASDAI score, ASDAS score) and reason for drug discontinuation.

TABLE 1. Demographic and baseline disease characteristics

\begin{tabular}{|c|c|c|c|c|c|}
\hline & $\begin{array}{l}\text { All axSpA patients } \\
\qquad n=616\end{array}$ & $\begin{array}{c}\text { biologic naïve } \\
\text { patients } \\
n=226\end{array}$ & $\begin{array}{c}1 \text { prior bDMARDs } \\
n=220\end{array}$ & $\begin{array}{c}\geq 2 \text { prior } \\
\text { bDMARDs } \\
n=170\end{array}$ & $\begin{array}{c}p \\
\text { value }\end{array}$ \\
\hline Age (years, mean \pm SD) & $49.04 \pm 12.07$ & $47.92 \pm 12.12$ & $49.68 \pm 11.84$ & $49.7 \pm 12.25$ & 0.2 \\
\hline Men (\%) & 73.4 & 74.8 & 72.3 & 72.9 & 0.8 \\
\hline $\begin{array}{l}\text { Disease duration } \\
\text { (years, mean } \pm S D \text { ) }\end{array}$ & $12.63 \pm 9.54$ & $10.22 \pm 10.03$ & $13.95 \pm 9.13$ & $14.14 \pm 8.73$ & $<0.001$ \\
\hline $\begin{array}{l}\text { Disease duration at biologic start } \\
\text { (years, mean } \pm S D \text { ) }\end{array}$ & $11.09 \pm 9.45$ & $8.81 \pm 10.03$ & $12.38 \pm 9.04$ & $12.46 \pm 8.62$ & $<0.001$ \\
\hline Current smokers (\%) & 13.3 & 17.3 & 12.3 & 9.4 & 0.07 \\
\hline $\begin{array}{l}\text { Body mass index }(\mathrm{kg} / \mathrm{m} 2) \text { (mean } \\
\pm \mathrm{SD})\end{array}$ & $27.77 \pm 5.73$ & $27.71 \pm 5.42$ & $27.66 \pm 6.08$ & $27.99 \pm 5.73$ & 0.8 \\
\hline $\begin{array}{l}\text { C reactive protein }(\mathrm{mg} / \mathrm{L} \text { ) (mean } \\
\pm \mathrm{SD} \text { ) }\end{array}$ & $32.32 \pm 36.31$ & $30.92 \pm 33.03$ & $27.69 \pm 16.35$ & $40.18 \pm 41.33$ & 0.003 \\
\hline $\operatorname{ESR}(\mathrm{mm} / \mathrm{h})($ mean $\pm \mathrm{SD})$ & $42.47 \pm 25.63$ & $41.67 \pm 22.86$ & $38.28 \pm 24.42$ & $48.95 \pm 29.27$ & $<0.001$ \\
\hline BASDAI (mean \pm SD) & $5.97 \pm 2.21$ & $7.29 \pm 1.44$ & $5.16 \pm 2.27$ & $5.28 \pm 2.17$ & $<0.001$ \\
\hline ASDAS (mean \pm SD) & $4.02 \pm 1.04$ & $4.52 \pm 0.76$ & $3.60 \pm 1.09$ & $3.90 \pm 1.02$ & $<0.001$ \\
\hline $\begin{array}{l}\text { First biologic agent } \\
\text {-Adalimumab }(n, \%) \\
\text {-Etanercept }(n, \%) \\
\text {-Golimumab }(n, \%) \\
\text {-Infliximab }(n, \%) \\
\text {-Certolizumab }(n, \%) \\
\text {-unknown }(n, \%) \\
\end{array}$ & $\begin{array}{c}128(33 \%) \\
96(25 \%) \\
77(20 \%) \\
62(16 \%) \\
22(5 \%) \\
5(1 \%)\end{array}$ & Not applicable & $\begin{array}{c}77(35 \%) \\
63(29 \%) \\
32(15 \%) \\
42(19 \%) \\
2(1 \%) \\
3(1 \%) \\
\end{array}$ & $\begin{array}{c}51(30 \%) \\
33(19 \%) \\
45(26 \%) \\
20(12 \%) \\
20(12 \%) \\
2(1 \%) \\
\end{array}$ & \\
\hline
\end{tabular}

The comparisons between groups from the perspective of the prior use of biologics before secukinumab course were performed with ANOVA and chi square test ( $\times 2)$. 
TABLE 2. Secukinumab drug retention rate at 6 months and 12 months. Comparison between groups

\begin{tabular}{|l|c|c|c|c|c|}
\hline & $\begin{array}{c}\text { All axSpA patients } \\
\mathbf{n}=\mathbf{6 1 6}\end{array}$ & $\begin{array}{c}\text { biologic } \\
\text { naïve patients } \\
\mathbf{n}=\mathbf{2 2 6}\end{array}$ & $\begin{array}{c}\mathbf{1} \text { prior bDMARDs } \\
\mathbf{n = 2 2 0}\end{array}$ & $\begin{array}{c}\mathbf{2} \text { prior bDMARDs } \\
\mathbf{n}=\mathbf{1 7 0}\end{array}$ & $\begin{array}{c}\mathbf{p} \\
\text { value }\end{array}$ \\
\hline $\begin{array}{l}\text { Secukinumab drug } \\
\text { retention rate }\end{array}$ & & & & $61 \%$ & $<0.001$ \\
- at 6 months & $68 \%$ & $78 \%$ & $63 \%$ & $41 \%$ & $<0.001$ \\
- at 12 months & $49 \%$ & $58 \%$ & $45 \%$ & & \\
\hline
\end{tabular}

The comparison was performed using Kaplan Meier Log Rank test

To be included in the study, patients had to be $\geq 18$ years old, have a diagnosis of axSpA as judged by the treating rheumatologist and be exposed to secukinum$\mathrm{ab}$ for at least one treatment course.

The collected variables were processed with SPSS statistics, using distribution and analytic tests, as appropriate: analysis of the variance (ANOVA), chisquare, Kaplan Meier analysis with log-rank test.

\section{RESULTS}

The study included 616 patients with SpA, stratified based on prior exposure to bDMARD into 3 groups: a) patients naïve to biologics; b) patients treated with one prior bDMARDs; c) patients treated with at least two prior bDMARDs before starting on secukinumab.

The time period in which the data were collected began in 2017 (once secukinumab was available in our country) and ended on the 30th November 2020. Table 1 displays the demographic and baseline disease characteristics.

There was no difference between groups in terms of age and gender composition. By contrast, there was a significantly shorter disease duration, as well ase time from diagnosis until the start of secukinumab treatment, for the biologic naive group, compared to the patients already exposed to biologics.

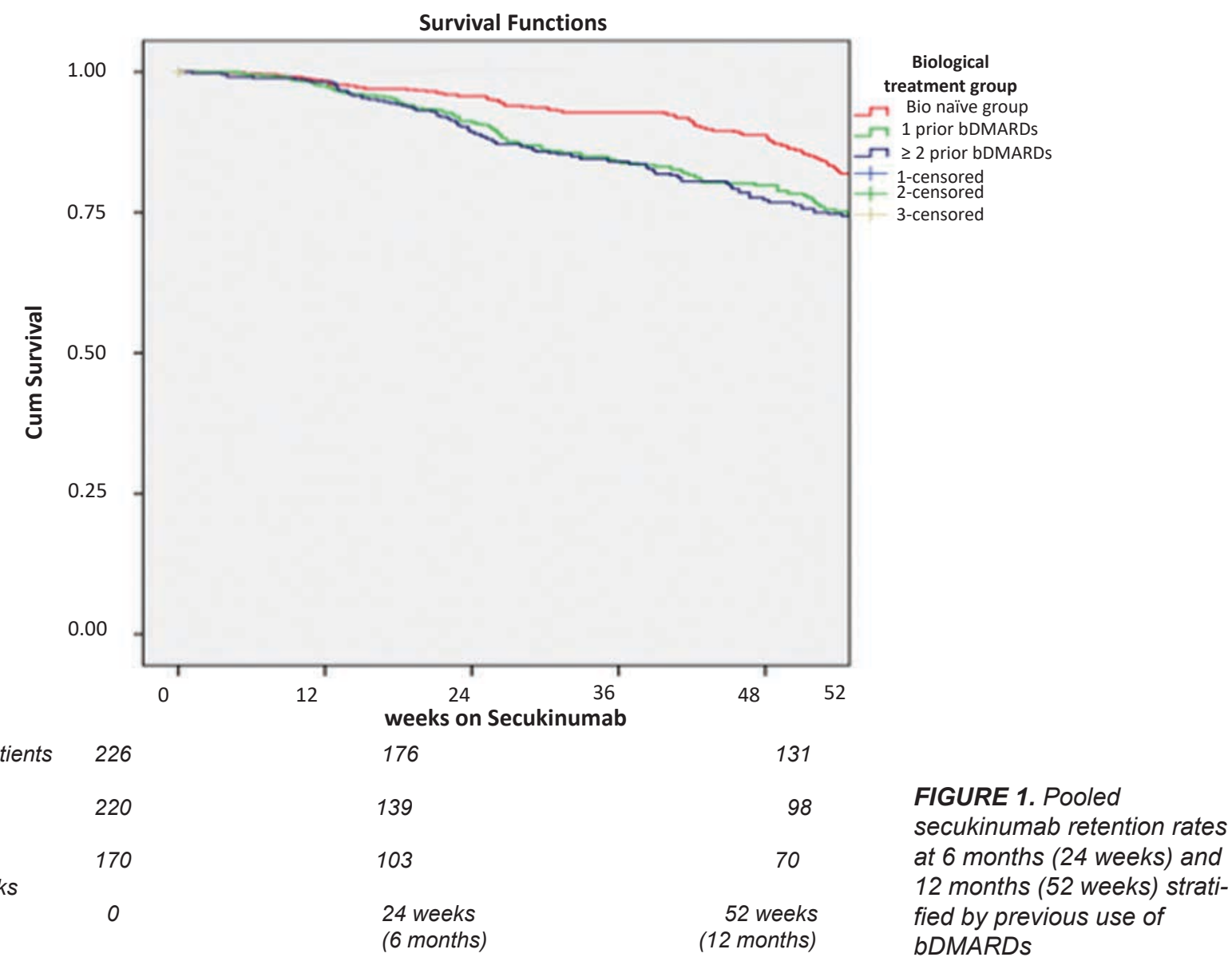




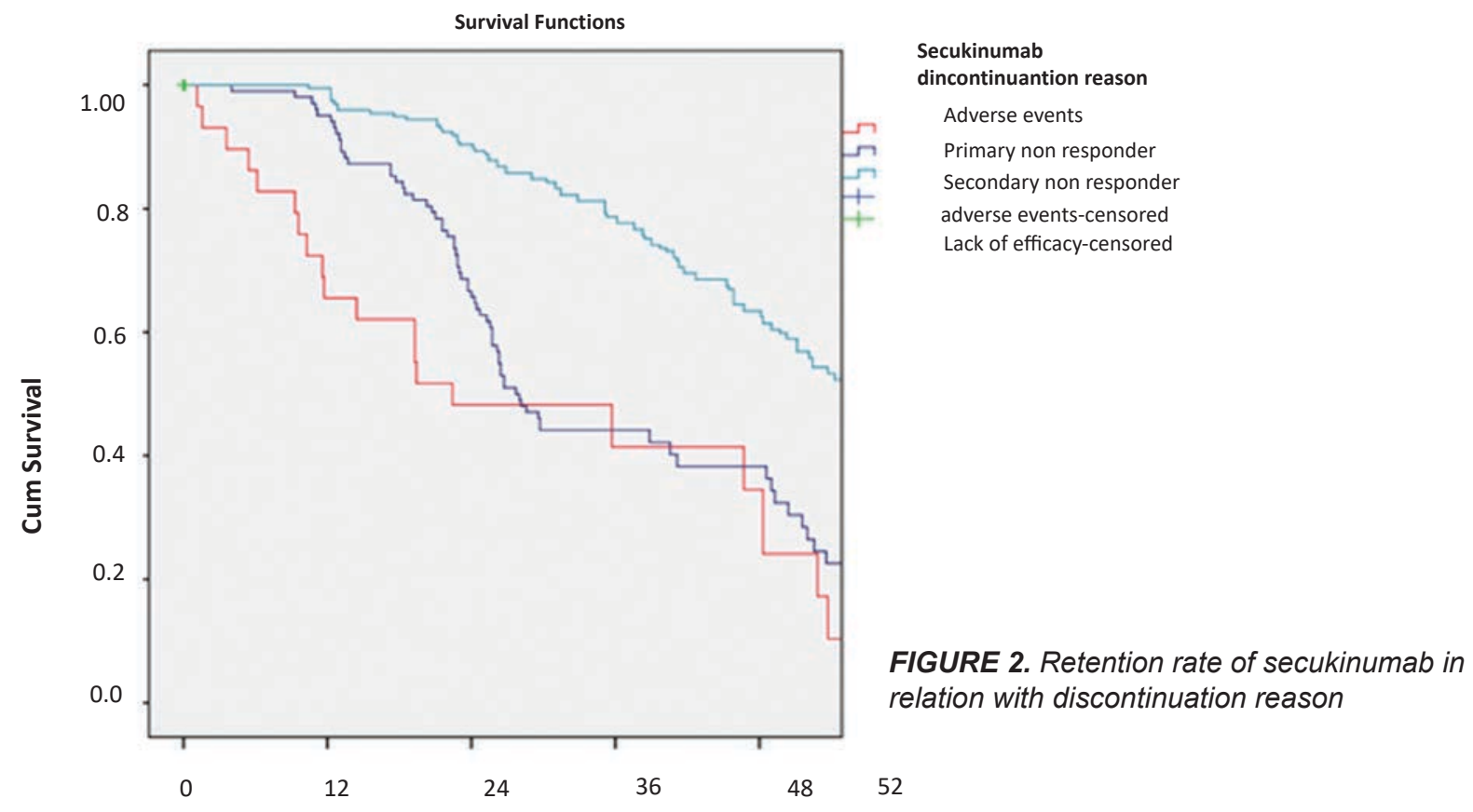

Both ESR and C reactive proteins at secukinumab milars) was the preferred biologic treatment in a second round of treatment. There is still a considerable percentage of patients using infliximab (original and biosimilars) as a first treatment option (19\%, 12\% respectively).

Secukinumab treatment retention rate (Table 2, Figure 1) was $68 \%$ at 6 months and $49 \%$ at 12 months. Analysing the clinical scenarios based on previous exposure to bDMARDS, there was a significant better retention rate at 6 months (78\%) and also at 12 months $(58 \%)$ for the bio-naïve group. bDMARDs started with Adalimumab (original and biosimilars), whereas etanercept (original and biosi-

TABLE 3. Secukinumab effectiveness after 6 months and 12 months of treatment

\begin{tabular}{|c|c|c|c|c|c|}
\hline & $\begin{array}{l}\text { All axSpA patients } \\
n=616\end{array}$ & $\begin{array}{c}\text { biologic naïve } \\
\text { patients } \\
n=226\end{array}$ & $\begin{array}{c}1 \text { prior bDMARDs } \\
n=220\end{array}$ & $\begin{array}{c}\geq 2 \text { prior bDMARDs } \\
n=170\end{array}$ & $\begin{array}{c}p \\
\text { value }\end{array}$ \\
\hline $\begin{array}{l}\text { BASDAI (mean } \pm \text { SD) } \\
\text { - at } 6 \text { months } \\
\text { - at } 12 \text { months }\end{array}$ & $\begin{array}{l}2.11 \pm 1.44 \\
1.66 \pm 1.23\end{array}$ & $\begin{array}{l}1.93 \pm 1.08 \\
1.79 \pm 1.19\end{array}$ & $\begin{array}{l}2.19 \pm 1.49 \\
1.50 \pm 1.28\end{array}$ & $\begin{array}{l}2.06 \pm 1.47 \\
1.62 \pm 1.18\end{array}$ & $\begin{array}{l}0.4 \\
0.1\end{array}$ \\
\hline $\begin{array}{l}\text { ASDAS (mean } \pm \text { SD) } \\
\text { - at } 6 \text { months } \\
\text { - at } 12 \text { months }\end{array}$ & $\begin{array}{l}2.15 \pm 0.73 \\
1.90 \pm 0.69\end{array}$ & $\begin{array}{l}1.90 \pm 0.62 \\
1.85 \pm 0.69\end{array}$ & $\begin{array}{l}2.21 \pm 0.77 \\
1.80 \pm 0.69\end{array}$ & $\begin{array}{l}2.16 \pm 0.70 \\
2.13 \pm 0.69\end{array}$ & $\begin{array}{c}0.02 \\
<0.001\end{array}$ \\
\hline $\begin{array}{l}\text { BASDAI < } 2 \\
\text { - at } 6 \text { months (\%) } \\
\text { - at } 12 \text { months (\%) }\end{array}$ & $\begin{array}{l}54 \% \\
66 \%\end{array}$ & $\begin{array}{l}43 \% \\
62 \%\end{array}$ & $\begin{array}{l}62 \% \\
69 \%\end{array}$ & $\begin{array}{l}62 \% \\
67 \% \\
\end{array}$ & $\begin{array}{c}0.01 \\
0.4\end{array}$ \\
\hline $\begin{array}{l}\text { BASDAI < } 4 \\
\text { - at } 6 \text { months (\%) } \\
\text { - at } 12 \text { months (\%) }\end{array}$ & $\begin{array}{l}91 \% \\
97 \%\end{array}$ & $\begin{array}{l}91 \% \\
95 \%\end{array}$ & $\begin{array}{l}90 \% \\
99 \%\end{array}$ & $\begin{array}{l}92 \% \\
97 \%\end{array}$ & $\begin{array}{l}0.3 \\
0.3\end{array}$ \\
\hline $\begin{array}{l}\text { ASDAS }<1.3 \\
\text { - at } 6 \text { months (\%) } \\
\text { - at } 12 \text { months (\%) }\end{array}$ & $\begin{array}{l}14 \% \\
19 \%\end{array}$ & $\begin{array}{l}16 \% \\
21 \%\end{array}$ & $\begin{array}{l}15 \% \\
20 \%\end{array}$ & $\begin{array}{c}8 \% \\
14 \%\end{array}$ & $\begin{array}{l}<0.001 \\
<0.001\end{array}$ \\
\hline $\begin{array}{l}\text { ASDAS }<2.1 \\
\text { - at } 6 \text { months (\%) } \\
\text { - at } 12 \text { months (\%) }\end{array}$ & $\begin{array}{l}53 \% \\
73 \%\end{array}$ & $\begin{array}{l}57 \% \\
74 \%\end{array}$ & $\begin{array}{l}57 \% \\
82 \%\end{array}$ & $\begin{array}{l}39 \% \\
57 \%\end{array}$ & $\begin{array}{l}<0.001 \\
<0.001\end{array}$ \\
\hline
\end{tabular}

The comparisons between groups from the perspective of the prior use of biologics before secukinumab course were performed with ANOVA and chi square test $\left(x^{2}\right)$. 
The main reason for discontinuation of secukinumab is loss of efficacy: secondary non-responders with 94 events. Primary non-responders were responsible for discontinuation in 28 events. Nine adverse events were also recorded as reason for discontinuation (Figure 2).

Similarly with other treatments, adverse events to secukinumab which are responsible for the treatment discontinuation are more frequent in the first 6 months of exposure; subsequently, the curve flattens. A relative similar behaviour is seen for primary non-responder patients. By contrast, secondary loss of efficacy appears late in time.

The effectiveness measures for secukinumab interventions at 6 months and 12 months of treatment used were BASDAI and disease activity score (ASDAS). From the literature, it is known that a level of BASDAI $>4$ reflects active disease. Because for BASDAI a clear cut-off value for inactive disease has not been validated, we used a cut-off value of 2 for inactive disease (in line with the one used in the EuroSpA study); a level of BASDAI between 2 and 4 corresponded in our analysis with low disease activity. For ASDAS, we have used the ASAS cut-off levels: inactive disease for ASDAS $<1.3$ and low disease activity for ASDAS $<2.1$ (11).

Table 3 displays the efficacy parameters for the entire secukinumab cohort, and compares groups based on previous exposure to bDMARDs.

Overall, at a cohort level, regardless of the score used to define efficacy, there is an improvement of BASDAI and ASDAS from 6 months to 12 months of treatment with secukinumab. At 6 months, the mean BASDAI corresponds to low disease activity, whereas mean ASDAS level stays in the high disease activity category; at 12 months, BASDAI drops to inactive disease state and ASDAS level decreased to low disease activity.

There are no major differences between different clinical scenarios related to previous bDMARDs exposure for BASDAI-6 months and BASDAI-12 months, except for BASDAI-6 months for biologic naïve patients ( $43 \%$ - significantly lower compared to $62 \%$ for the other groups). However when using ASDAS, biologic naïve patients have a significantly better treatment response to secukinumab at 6 months and at 12 months, being at low disease activity state from 6 months onwards. Patients previously exposed to biologics have a better response when a lower number of prior biologics were used: patients who received only 1 biologic before secukinumab reach low disease activity state at 12 months, whereas patients who received 2 or more biologic drugs stay in high disease activity even at 12 months.

Figure 3 and figure 4 display disease activity state after 6 months and after 12 months of treatment with secukinumab, with comparison between the 3 groups.

There were no differences between groups according to age and disease duration related to efficacy parameters.

\section{DISCUSSION}

The randomized controlled trials (RCT) are the gold standard for assessing the efficacy of pharmacological treatments and other interventions (12). Results from RCTs may, however, lack external validity (13) due to their highly standardized design, strict inclusion and exclusion criteria, and fixed treatment regimens that may often be at odds with real world conditions $(14,15)$. Patient characteristics may differ between RCTs and observational studies (registry data) and may modify treatment effects (16).

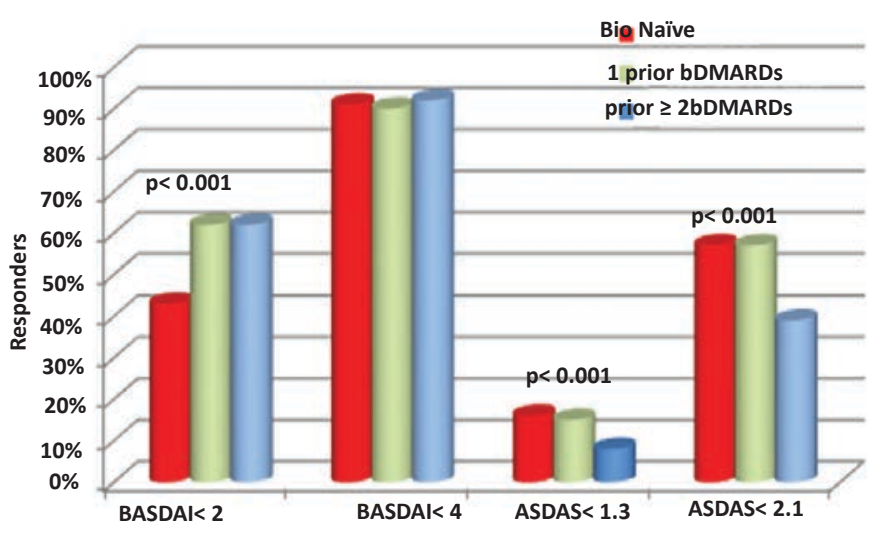

FIGURE 3. Disease state after 6 months of treatment with secukinumab compared across previous exposure bDMARDs

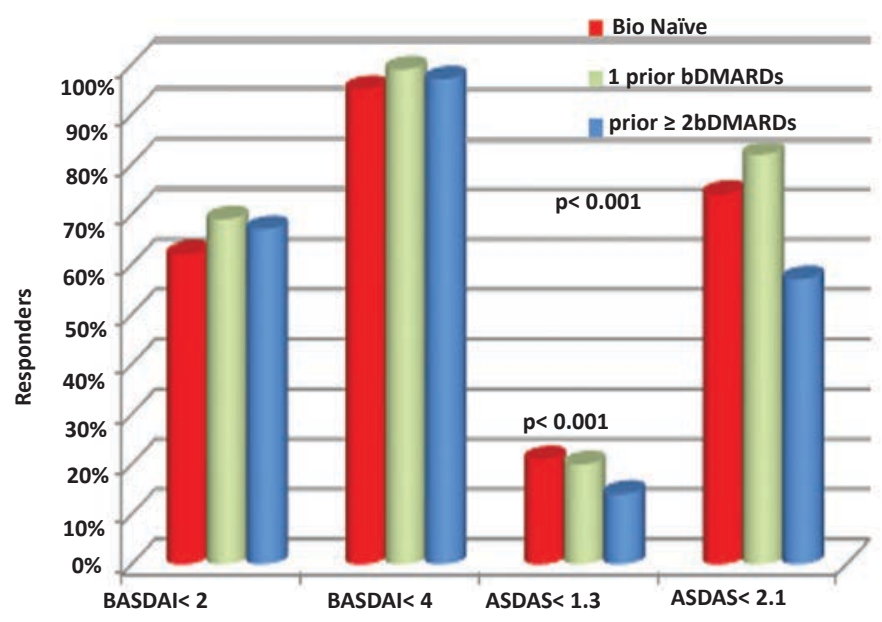

FIGURE 4. Disease state after 12 months of treatment with secukinumab compared across previous exposure bDMARDs 
The main disadvantage of registries data is lack of complete information (missing data) as well as a more subjective attribution of adverse events in severity classes; besides this, with increasing number of patients included in a report, the more dynamic the population is, the more valuable the information become. That is why reports from registries are extremely valuable in offering real world evidence of the patients and disease phenotypes, as well as effectiveness (rather than efficacy) and safety data. On the other hand, even from one registry to the other there may be large differences, based on geographical or socio-economic factors. Reports which include results from registry collaborations are important, but it is equally important to present national registry data.

This is the first report on retention rate of a biologic treatment performed on data extracted from the RRBR database. We choose to present retention rate for secukinumab in SpA, because RRBR is a contributor to EuroSpA network which has recently published a comprehensive analysis on retention rate for secukinumab in 13 European Registries.

Comparing our results to the EuroSpA results, on one hand the retention rate of secukinumab in RRBR at 6 months and 12 months is lower globally as well as in each individual group differentiating between

\section{REFERENCES}

1. Zeidler $\mathrm{H}$, Amor B. The Assessment in Spondyloarthritis International Society (ASAS) classification criteria for peripheral spondyloarthritis and for spondyloarthritis in general: the spondyloarthritis concept in progress. Ann Rheum Dis. 2011 Jan;70(1):1-3.

2. Zeidler $\mathrm{H}$, Calin A, Amor B. A historical perspective of the spondyloarthritis. Curr Opin Rheumatol. 2011 Jul;23(4):327-33.

3. Kiltz U, Baraliakos X, Karakostas P, Igelmann M, Kalthoff L, Klink C, Krause D, Schmitz-Bortz E, Flörecke M, Bollow M, Braun J. Do patients with non-radiographic axial spondylarthritis differ from patients with ankylosing spondylitis? Arthritis Care Res (Hoboken). 2012;64(9):1415.

4. van der Heijde D, Ramiro S, Landewe R, et al. 2016 update of the ASAS-EULAR management recommendations for axial spondyloarthritis. Ann Rheum Dis. 2016;2017:978-91.

5. Patel DD, Lee DM, Kolbinger F, Antoni C. Effect of IL-17A blockade with secukinumab in autoimmune diseases. Ann Rheum Dis. 2013 Apr;72 Suppl 2:ii116-23.

6. Ørnbjerg LM, Brahe $\mathrm{CH}$, Askling J, et al. Treatment response and drug retention rates in 24,195 biologic-naive patients with axial spondyloarthritis initiating TNFi treatment: routine care data from 12 registries in the EuroSpA collaboration. Ann Rheum Dis. 2019;78:1536-44

7. Brahe $\mathrm{CH}$, Ørnbjerg LM, Jacobsson L, Nissen MJ, Kristianslund EK, Mann H, Santos MJ, Reino JG, Nordström D, Rotar Z, Gudbjornsson B et al. Retention and response rates in 14,261 PsA patients starting TNF inhibitor treatment-results from 12 countries in EuroSpA. Rheumatology (Oxford). 2020 Jul 1;59(7):1640-1650.

8. Michelsen B, Ørnbjerg LM, Kvien TK, et al. Impact of discordance between patient's and evaluator's global assessment on treatment
bDMARDs prior use. One possible reason for this difference is the Romanian Protocol for Biologic Use which stipulates rigorous responder criteria after the first 6 months of treatment exposure and at each subsequent efficacy evaluation. These criteria may influence the number of patients that can continue the treatment with a particular drug. Another possible factor refers to the number of patients included in this study (616) consistently higher that number of patients included from RRBR in EuroSpA study (301) (because of the time period of enrolment). On the other hand, effectiveness results are much better, disease state of inactivity and low activity is numerically higher, at 6 months and also at 12 months, comprising more patients at group level and also at cohort level. The EuroSpA report also notes high levels of variability in secukinumab effectiveness across different registries.

\section{CONCLUSIONS}

Our results show that the best retention rate for secukinumab treatment, as well as efficacy, is attained for the bio-naive treatment group. The main reason for discontinuation of secukinumab treatment is secondary loss of efficacy.

Conflict of interest: none declared Financial support: none declared

outcomes in 14,868 patients with spondyloarthritis. Rheumatology (Oxford). 2020.

9. Michelsen B, Lindström U, Codreanu C, Ciurea A et al. Drug retention, inactive disease and response rates in 1860 patients with axial spondyloarthritis initiating secukinumab treatment: routine care data from 13 registries in the EuroSpA collaboration. RMD Open. 2020 Sep;6(3):e001280.

10. Codreanu C, Mogosan C, Ionescu R, Ancuta I, Opris D. Biologic Therapy in Rheumatoid Arthritis: Results from the Romanian Registry of Rheumatic Diseases One Year After Initiation. Farmacia. 2014;62(6):1089-96.

11. Machado P, Landewe R, Lie E, et al. Ankylosing Spondylitis Disease Activity Score (ASDAS): defining cut-off values for disease activity states and improvement scores. Ann Rheum Dis. 2011;70:47-53.

12. GreenlandS, Pearl J, Robins JM. Causal diagrams for epidemiologic research. Epidemiology. 1999;10:37-48.

13. Stuart EA, Bradshaw $C P$, Leaf PJ. Assessing the generalizability of randomized trial results to target populations. Prev Sci Off J Soc Prev Res- 2015;16:475-85.

14. Furst DE. Observational cohort studies and well controlled clinical trials - we need them both! J Rheumatol. 2004;31:1476-7.

15. Pincus T, Sokka T. Should contemporary rheumatoid arthritis clinical trials be more like standard patient care and vice versa? Ann Rheum Dis. 2004 Nov;63(Suppl 2):ii32-ii39.

16. Stuart EA, Cole SR, Bradshaw CP, Leaf PJ. The use of propensity scores to assess the generalizability of results from randomized trials. J R Stat Soc Ser A Stat Soc. 2011;174:369-86. 